Research Report No. 24/2011

\title{
Comparative, Global and Transnational Constitutionalism: The Emergence of a Transnational Legal-Pluralist Order
}

Peer Zumbansen

Osgoode Hall Law School of York University, PZumbansen@osgoode.yorku.ca

Follow this and additional works at: http://digitalcommons.osgoode.yorku.ca/clpe

\section{Recommended Citation}

Zumbansen, Peer, "Comparative, Global and Transnational Constitutionalism: The Emergence of a Transnational Legal-Pluralist Order" (2011). Comparative Research in Law \& Political Economy. Research Paper No. 24/2011.

http://digitalcommons.osgoode.yorku.ca/clpe/62 


\section{OSGOODE}

OSGOODE HALL LAW SCHOOL

YOR K U N I VERSITY

\section{OSGOODE HALL LAW SCHOOL}

Comparative Research in Law \& Political Economy

RESEARCH PAPER SERIES

Research Paper No. 24/2011

Comparative, Global and Transnational Constitutionalism: The Emergence of a Transnational Legal-Pluralist Order

Peer Zumbansen

\section{Editors:}

Peer Zumbansen (Osgoode Hall Law School, Toronto, Director, Comparative Research in Law and Political Economy)

John W. Cioffi (University of California at Riverside) Lisa Phillips (Osgoode Hall Law School, Professor of Law)

Leeanne Footman (Osgoode Hall Law School, Toronto, Production Editor) 
Osgoode CLPE Research Paper 24/2011

Vol. 07 No. 06 (2011)

Peer Zumbansen

\title{
Comparative, Global and Transnational Constitutionalism: The Emergence of a Transnational Legal-Pluralist Order
}

\begin{abstract}
Comparative lawyers have for more than one-hundred years sought to increase the understanding of 'foreign' legal orders and regulatory systems. Despite some never fully resolved methodological questions, great advances have been made in the comparative study of different regulatory areas both in 'private' (contract, tort, corporate, labour) and 'public' law (administrative law, environmental law). Comparative constitutional law [CCL] has emerged as a field with particular significance. Born in the context of a politically extremely divided world after the Second World War, CCL has undergone tremendous change in an economically fast-integrating world since the late 1980s. The distinction between 'liberal' and 'socialist' constitutional orders that characterized early monographical treatments of the subjects has since given way to a very incoherent landscape of varieties of constitutionalism, with enormous consequences for the task of comparative constitutional law. Rather than being able to set side-by-side distinct doctrinal instruments or legal principles that can be associated with a particular constitutional system, the emerging transnational legal-pluralist order demands a methodologically radically opened and methodologically interdisciplinary approach to capture the dynamics of constitutionalization, which characterize today's processes of public-private norm creation and diffusion.
\end{abstract}

Key words: Comparative Law, Comparative Constitutionalism, Legal Pluralism, Global Governance, Transnational Law

Forthcoming in: 1:1 Global Constitutionalism (2012)

Professor Peer Zumbansen

Canada Research Chair

Osgoode Hall Law School

York University, Toronto

Director, Critical Research Laboratory in Law \& Society

E: PZumbansen@osgoode.yorku.ca

SSRN Author: http://ssrn.com/author=109516 


\section{Comparative, Global and Transnational Constitutionalism: The Emergence of a Transnational Legal-Pluralist Order}

\section{Peer Zumbansen*}

\section{Introduction: The Global Context of Comparative Constitutionalism}

From its first iterations, comparative law was destined to be a two-way street. To the degree that the comparatist would 'discover' and 'learn' about the rules, institutions and legal routines in 'foreign' lands, she would most importantly find herself thrown back unto herself, confronted with her own idiosyncrasies, her background and 'culture', now less starry-eyed as concerns her own legal system. ${ }^{1}$ Despite the persistence with which protagonists of comparative ${ }^{2}$ or 'world' law ${ }^{3}$ made claims of law's universal progress, doubt inevitably began to creep into an ever more elaborate edifice of comparative law, and it was not long that the wellmeaning, yet ideologically naïve impetus of comparative law was aptly exposed and laid out for all to see. ${ }^{4}$ Meanwhile, now at just over 110 years old, comparative law has not died or withered entirely. ${ }^{5}$ As an element of crucial importance in a system of considerably parochially national legal education ${ }^{6}$, the value of comparative law is highlighted with view to the graduating students' need to 'know more about the world 7 and to be better equipped to aptly move from one 'secondment' to the next. ${ }^{8}$ And yet, comparative law in its own right is not on the rise in law school faculties around the world, surely not as a mandatory or, as such, as a subject in high demand from students. The question whether that can be solely accredited to the field's

\footnotetext{
* Professor of Law and Canada Research Chair, Osgoode Hall Law School, York University, Toronto. Email: PZumbansen@osgoode.yorku.ca ${ }^{1}$ Günter Frankenberg, 'Critical Comparisons: Re-Thinking Comparative Law', (1985) 26 Harvard International Law Journal (Harv. Int'l L.J.) 411-455

${ }^{2}$ Konrad Zweigert/Hein Kötz, An Introduction to Comparative Law, 3rd ed. (1996)

${ }^{3}$ Harold J. Berman, 'World Law', (1995) 18 Fordham International Law Journal 1617-1622

${ }^{4}$ Otto Kahn-Freund, 'On Use and Misuse of Comparative Law', (1974) 37 Modern Law Review 1-27; Jonathan Hill, 'Comparative Law, Law Reform and Legal Theory', (1989) 9 Oxford Journal of Legal Studies 101-115; Frankenberg, note 1

${ }^{5}$ But, see the sobering notes by Ralf Michaels, 'Im Westen nichts Neues?' (2003) 66 RabelsZ 97-115

${ }^{6}$ See the contributions to the $10^{\text {th }}$ Anniversary German Law Journal Symposium on 'The Transnationalization of Legal Cultures', June-July 2009, 1291-1416, available at: http://www.germanlawjournal.com/pdfs/FullIssues/PDF Vol 10 No 10 Complete\%20Issue.pdf
}

${ }^{7}$ Catherine Valcke, 'Global Law Teaching', (2004) 54 J. Legal Educ. 160; Mathias Reimann, 'From the Law of Nations to Transnational Law: Why We Need a New Basic Course for the International Curriculum', (2004) 22 Penn State International Law Review 397-415

8 Roy T. Stuckey, 'Preparing Students to Practice Law: A Global Problem in Need of Global Solutions', (2002) 43 South Texas Law Review 649 
never-ending methodological self-doubts ${ }^{9}$ or to the overwhelming influence of practitioner lobbying onto law school curricula with view to include more practical training opportunities in the students' legal education ${ }^{10}$ does not necessitate a satisfying or clear-cut answer. Meanwhile, what appears to be a more significant development is the gradual approximation of formerly distinct perspectives on the evolution of the legal system in a process which gives way to the emergence of a multi-layered, pluralist regulatory architecture. In manifold fields of legal regulation, including contract ${ }^{11}$, tort ${ }^{12}$, environmental ${ }^{13}$ or corporate law ${ }^{14}$, we have been able to witness a remarkable expansion of the outside boundaries of the respective fields to elements of comparison, integration, assimilation. This development goes far beyond the traditional zeal of comparative law, in that experts in a particular field now find themselves inevitably and unavoidably confronted with a fast-changing regulatory and institutional landscape. Confronted with the intricacies of a further evolving transnational regulatory architecture consisting of both public and private, hybrid norm creation systems, no longer exclusively located on either on a domestic or international level, we are prompted - in theory and practice - to engage in methodological introspection. In other words, it becomes a natural part of legal research, case preparation and problem solving to integrate legal solutions, principles and rules from a variety of legal levels and cultures. ${ }^{15} \mathrm{As}$ a result, the boundaries between distinctly perceived legal and political, jurisdictionally and systemically perceived systems begin to fade, while the contours of specialized, sectorial and functional regulatory regimes become more

\footnotetext{
${ }^{9}$ Ralf Michaels, 'The Functional Method in Comparative Law', in Ralf Michaels (ed) Oxford Handbook of Comparative Law (2006); Peer Zumbansen, 'Comparative Law's Coming of Age? Twenty Years after 'Critical Comparisons", (2005) 6 German Law Journal 1073-1084

${ }^{10}$ See eg 'Washington and Lee School of Law Announces Dramatic Third Year Reform', 10 March 2008, available at: http://law.wlu.edu/news/storydetail.asp?id=376
}

${ }^{11}$ W. Carl Kester, 'Governance, Contracting, and Investment Horizons: A Look at Japan and Germany', in W. Carl Kester (ed) Studies in International Corporate Finance and Governance Systems. A Comparison of the U.S., Japan and Europe (1997)

${ }^{12}$ Craig M. Scott, 'Introduction to Torture as Tort: From Sudan to Canada to Somalia', in Craig M. Scott (ed) Torture as Tort (2001)

13 Jutta Brunnée, 'Of Sense and Sensibility: Reflections on International Liability Regimes as Tools for Environmental Protection', (2004) 53 International and Comparative Law Quarterly 351-367

${ }^{14}$ Klaus Jürgen Hopt, 'Comparative Company Law', in Klaus Jürgen Hopt (ed) Oxford Handbook of Comparative Law (2006); Peer Zumbansen, 'Neither `Public' nor `Private', `National' nor 'International': Transnational Corporate Governance from a Legal Pluralist Perspective', (2011) 38 Journal of Law \& Society 50-75

${ }^{15}$ Antje Wiener, 'Contested Meanings of Norms: A Research Framework', (2007) 5 Comparative European Politics 1-17, 2: "...under conditions of transnationalization the regulatory practices of modern constitutionalism are increasingly moved out of the social contexts of their modern i.e. Hegelian conception. Subsequently, interpretation of the principles and norms of governance depends increasingly on cultural practices." 
accentuated. ${ }^{16}$ It is this - transnational and pluralist - landscape that this article focuses on in order to identify and then to problematize some of the defining characteristics, which mark one of the most significantly 'globalizing' legal fields namely: constitutional law. In light of the immensely rich work done in comparative and global constitutional law and, with great promise, constitutionalism, up to the present day, the following article posits constitutionalism as a conceptual framework constituted by an intersection and interplay of both institutional and normative conceptions of political, legal, cultural and economic order. "Constitutionalism [...] is associated with the study of the constitutive elements of legal and political practice that are central for the assessment of its legality or legitimacy." 17 And, precisely because of its encompassing and absorbing nature, it is necessary to unfold and unpack the concept of constitutionalism to render visible the various disciplinary perspectives and approaches as well as the different normative conceptualizations and background assumptions that have been feeding, on the one hand, into the current and not always neatly distinguishable, legalpolitical deliberations around 'international'18, 'global'19 and 'transnational'20 constitutionalism', 'cosmopolitanism'21, 'pluralism'22 in a considerably wide theoretical ambit, and into a slightly more confined, legally argumentative

${ }^{16}$ For the examples of transnational contract and corporate law, see Gralf-Peter Calliess/Peer Zumbansen, Rough Consensus and Running Code: A Theory of Transnational Private Law (2010), ch. 3, ch. 4 .

${ }^{17}$ Antje Wiener, 'Global Constitutionalism: Mapping an Emerging Field' (2011), Paper prepared for the Conference Constitutionalism in a New Key? Cosmopolitan, Pluralist and Public Reason-Oriented, Berlin, Wissenschaftszentrum and Humboldt University, 28-29 January 2011, available at: http://cosmopolis.wzb.eu/content/program/conkey_Wiener_Mapping-Field.pdf, at 2.

18 Bardo Fassbender, 'The United Nations Charter as Constitution of the International Community', (1998) 36 Columbia Journal of Transnational Law 529-619; Christian Walter, 'Constitutionalizing (Inter)national Governance - Possibilities and Limits to the Development of an Inernational Constitutional Law', (2001) 44 German Yearbook of International Law 170-201

${ }^{19}$ Anne Peters, 'The Merits of Global Constitutionalism', (2009) 16 Indiana Journal of Global Legal Studies 397-411; Jeffrey L. Dunoff/Joel P. Trachtman, 'A Functional Approach to Global Constitutionalism', in Jeffrey L. Dunoff/Joel P. Trachtman (eds), Ruling the World? Constitutionalism, International Law and Global Governance (2009); see also, for a differentiated position, which seeks to mediate between the structures and potentialities of national and international constitutionalism: Mattias Kumm, 'The Legitimacy of International Law: A Constitutionalist Framework of Analysis', (2004) 15 Eur. J. Int'l L. 907-931.

${ }^{20}$ Nicholas Tsagourias (ed) Transnational Constitutionalism: International and European Models (2007)

21 David Held, 'Cosmopolitanism', (2006) Stanford Encyclopedia of Philosophy (28 November 2006) http://plato.stanford.edu/entries/cosmopolitanism; Daniele Archibugi, 'Cosmopolitan Democracy and Its Critics: A Review', (2004) 10 European Journal of International Relations 437-473

${ }^{22}$ See, James Tully, 'The Unfreedom of the Moderns in Comparison to Their Ideals of Constitutional Democracy', (2002) 65 Modern Law Review 204-228, Jean L. Cohen, 'A Global State of Emergency or the Further Constitutionalization of International Law: A Pluralist Approach', (2008) 15 Constellations 456-484, and Nico Krisch, Beyond Constitutionalism. The Pluralist Structure of Postnational law (2010). 
battleground around the promises and challenges of 'global administrative law'23, on the other.

The purpose of this article is first to outline and to assess the yard sticks and measurements relied upon in comparative constitutional thought before opening the spectrum to a much wider and encompassing view on the emergence of a transnational and pluralist constitutional order. Such an inquiry not only unfolds in but also overlaps and shares concerns with an already extremely rich context of investigations into the prospects of the rule of law 'beyond the state'24, the institutional architecture ${ }^{25}$ as well as the normative underpinnings of 'global governance'. ${ }^{26}$ The theoretical and conceptual density of the pertinent debates today around global governance and global constitutionalism is illustrative of the importance of interdisciplinary - and critical - dialogue and engagement. ${ }^{27}$ Precisely because of the plurality of voices and disciplinary approaches in this debate, it becomes even more relevant to carve out the various perspectives and frameworks, from which scholars have been conceptualizing problems of political, legal and economic order on the global scale. This will provide the basis on which we can see the emergence of a concept of transnational constitutionalism. In a first step, a closer look at the transformation of comparative constitutionalism, predominantly in legal and political sciences, will offer valuable insights in the layered and complex nature of constitutionalism. The next step (III) will be to contextualize this concept in association with the sociological theory of a functionally differentiated world society, before section IV offers an analysis of the tensions between form and substance concerns within the concept of constitutionalism. In conclusion, section $\mathrm{V}$

\footnotetext{
${ }^{23}$ Benedict Kingsbury/Nico Krisch/Richard Stewart, 'The Emergence of Global Administrative Law', (2005) 68 Law \& Contemporary Problems 15-61; for alternative and challenging views, see eg Carol Harlow, 'Global Administrative Law: The Quest for Principles and Values', (2006) 17 European Journal of International Law 187-214, B.S. Chimni, 'Co-option and Resistance: Two Faces of Global Administrative Law', (2005) 37 New York University Journal of International Law \& Politics 799-827, and Susan Marks, 'Naming Global Administrative Law', (2005) 37 New York University Journal of International Law and Politics 995-1001. For an alternative project addressing the 'public' nature of global governance through legal institutions, see Armin Bogdandy/Philipp Dann/Matthias Goldmann, 'Developing the Publicness of Public International Law', (2008) 9 German Law Journal 1375-1400, and the ensuing contributions to the symposium, id.

${ }^{24}$ Benedict Kingsbury, 'The Concept of 'Law' in Global Administrative Law', (2009) 20 Eur. J. Int'l L. 23-57

${ }^{25}$ Michael Zürn, 'Globalization and global governance: from societal to political denationalization', (2003) 11 European Review 341-364

26 David Held, 'Reframing Global Governance: Apocalypse Soon or Reform!' in David Held (ed) Globalization Theory. Approaches and Controversies (2007); Mathias Koenig-Archibugi, 'Global governance', in Mathias Koenig-Archibugi (ed) The Handbook of Globalisation (2003); David Kennedy, 'Challenging Expert Rule: The Politics of Global Governance', (2005) 27 Sydney Law Review $1-24$

27 Christine E.J. Schwöbel, 'Organic Global Constitutionalism', (2010) 23 Leiden Journal of International Law 529-553
} 
places the concept of constitutionalism in the wider context of a theory of law and society.

\section{The Conundrical Nature of Comparison: Politics, Law, Culture}

At the outset it is necessary to clarify whether we are to be concerned with a substantive comparison of constitutions as exercised - for example - by Aristotle in Politics, or with a formal one, which focuses on distinctions between written and unwritten, traditional or revolutionary constitutions and their complementing institutional orders, as has become routine in modern day political and constitutional thought. Comparisons in both directions are available ${ }^{28}$ and it is against this background, that we can here attempt to engage in a series of conceptual and theoretical reflections on the exercise and practice of comparative constitutional law.

While such efforts are in order for a number of reasons that will be spelled out momentarily, at the same time it puts into question the conceptual framework that we are meant to apply and pre-suppose. A focus on 'different systems' or, constitutional 'orders' suggests that we can (still) readily draw such distinctions and it would still be a promising endeavour to reach deep within them in order to assess and interpret recognizable differences in the design, practice and culture of constitutional design. In fact, much suggests that the foundations on which we can base the identification and demarcation of distinct constitutional systems pertains more to historic than systematic evidence. In other words, we need to ask whether or not the increasing 'migration of constitutional ideas'29, the phenomenon of 'judicial globalization' 30 and the impregnation of constitutional cultures through 'foreign' norms and principles ${ }^{31}$, while reflecting on a considerable degree of transformation, opening and 'internationalization', still leaves the systematic structure intact. $^{32}$ Not unknown from the field of comparative law in general ${ }^{33}$, also

${ }^{28}$ Mauro Cappelletti/William Cohen, Comparative Constitutional Law (1979); Durga Das Basu, Comparative Constitutional Law (1984); Vicki C. Jackson/Mark Tushnet, Comparative Constitutional Law 2nd. ed. (2006); Norman Dorsen/Michel Rosenfeld/András Sajó/Susanne Baer, Comparative Constitutionalism. Cases and Materials. 2nd ed. (2010), $36 \mathrm{ff}$

${ }^{29}$ Sujit Choudhry (ed) The Migration of Constitutional Ideas (2006)

${ }^{30}$ Anne-Marie Slaughter, 'Judicial Globalization', (2000) 40 Virginia Journal of International Law 1103-1124

31 Gérard V. La Forest, 'The Expanding Role of the Supreme Court of Canada in International Law Issues', (1996) 34 Canadian Yearbook of International Law 89; Louise Arbour/Fannie Lafontaine, 'Beyond Self-Congratulation: The Charter at 25 in an International Perspective', (2007) 45 Osgoode Hall Law Journal 239-275

32 But see: Sujit Choudhry, 'Globalization in Search of Justification: Toward a Theory of Comparative Constitutional Interpretation', (1999) Indiana Law Journal 819-892, 941: “A court's choice of interpretive methodology will affect more than the outcome the particular case before it. It will also likely affect the broader constitutional culture of the interpreting court's jurisdiction." 
constitutional comparisons are still plagued by a great degree of methodological uncertainty and theoretical indeterminacy. But, while "[c]onstitutionalism is sweeping the world" 34 , evidenced for example by "at least 110 countries around the world" engaged in constitution writing or reform since $1990^{35}$, this evidence is itself extremely varied. Both causes and forms of constitutional change are anything but uniform and thus belie all claims regarding a world-wide and universal trend to a specific set of constitutional values or rights. Rather, the intensity of constitutional creation, reform and discourse around the world is illustrative of the complexity of this process. The search, thus, for an analytical architecture of typologies across these myriad and continuously evolving constitutionalist cultures must reach deep into the constitutive elements of legal and political cultures, where the places, forms and scopes of democracy continue to be 'unsolved riddles'. ${ }^{36}$

\section{Methodological Orientation}

In the present article I want to suggest that the just described influences illustrate the emergence of a transnational culture of constitutionalism. The importance here lies in the combination of transnational and constitutionalism on the basis of a methodological critique and inquiry 37 , with each term taken to be hiding more than it is revealing or, even less, self explanatory. Importantly, the term transnational does not merely signify the extension of - however institutionalized or formalized normativity across borders, say, of nation states or other jurisdictional confines. Instead, the term transnational identifies an intricate connection of spatial and conceptual dimensions: in addressing, on the one hand, the demarcation of emerging and evolving spaces and, on the other, the construction of these spaces as artifacts for human activity, communication and rationality, the term transnational is conceptual. To declare an activity as being transnational is not just the result of an empirical observation, say, of a border crossing commercial transaction. ${ }^{38}$ Instead, the term transnational prompts a closer scrutiny of the definitional work that has

\footnotetext{
33 Otto Kahn-Freund, Comparative Law as an Academic Subject. Inaugural lecture delivered before the University of Oxford on 12 May 1965 (1965); Otto Kahn-Freund, 'On Use and Misuse of Comparative Law', (1974) 37 Modern Law Review 1-27; Pierre Legrand, Le droit comparé (1999); Russell A. Miller, 'Introduction', in Russell A. Miller (ed) Global Legal Traditions: Comparative Law in the Twenty-First Century (2012)

34 Susan H. Williams, 'Introduction: Comparative Constitutional Law, Gender Equality, and Constitutional Design', in Susan H. Williams (ed) Constituting Equality. Gender Equality and Comparative Constitutional Law (2009), 1

35 Ibid.

36 Susan Marks, The Riddle of All Constitutions. International Law, Democracy, and the Critique of Ideology (2000), 103, 146.

${ }^{37}$ It is in this respect that this approach differs from the one taken by Nicholas Tsagourias (ed) Transnational Constitutionalism: International and European Models (2007).

38 Ross Cranston, 'Theorizing Transnational Commercial Law', (2007) 42 Texas International Law Journal 597-617
} 
gone into the description of the space before transnationalization. This line of questioning is of crucial importance as it reveals that the drawing of boundaries and the demarcation of 'spaces' is a conceptual undertaking. ${ }^{39}$ Seen in this light, the imagery of 'constitutionalism beyond the state' is open for a conceptual inquiry as to the irreplaceable or alternative-less inscription of constitutionalism within the state. ${ }^{40}$ To investigate the transnational nature of institutions or processes, in other words, is a methodological inquiry into the very structure of the language with which spaces of activity, regulation and governance are constructed.

Thus, when speaking of transnational constitutionalism, we should not think of a normative order that emerges autonomously outside of the confines of the nation state and, as such encompasses a distinct space of global governance with no relation to the world of states and the correlating measurements of law, namely national and international. Instead, transnational constitutionalism expresses the continuing evolution of constitutional principles, instruments and doctrines as a particular form of legal evolution today. Transnational constitutionalism radically challenges but does not negate the distinction between the domestic and the international legal order. As suggested already in the 1950s by scholars in public and private law, the idea of 'transnational law' could aptly capture the emergence of norm creation and enforcement outside of the confines of both private and public international law. ${ }^{41}$ These propositions, which have over time resonated in different areas of law, predominantly in commercial law and other subject areas of 'private' ${ }^{l a w^{42}}$, have furthermore inspired a host of theoretical and conceptual work around legal pluralism ${ }^{43}$, human rights law ${ }^{44}$ and transnational legal theory. ${ }^{45}$ Central to these approaches are two insights, one relating to the overwhelming evidence of

\footnotetext{
39 Richard Ford, 'Law's Territory (A History of Jurisdiction)', (1999) 97 Michigan Law Review 843; Yishai Blank, 'Localism in the Global Legal Order', (2006) 47 Harvard International Law Journal 263281

40 Neil Walker, 'Taking Constitutionalism Beyond the State', (2008) 56 Political Studies 519-543, 523

${ }^{41}$ Philip C. Jessup, Transnational Law (1956); Wolfgang G. Friedmann, 'Corporate Power, Government by Private Groups, and the Law', (1957) 57 Columbia Law Review 155-186;

42 Berthold Goldman, 'Arbitrage International et droit commun des nations', (1956) Revue de l'Arbitrage 115; Clive M. Schmitthoff, 'International Business Law: A New Law Merchant', (1961) 2 Current Law and Social Problems 129-153; Gralf-Peter Calliess/Peer Zumbansen, Rough Consensus and Running Code: A Theory of Transnational Private Law (2010)

${ }^{43}$ Gunther Teubner, "Global Bukowina': Legal Pluralism in the World Society', in Gunther Teubner (ed) Global Law Without A State (1997); Sally Engle Merry, 'New Legal Realism and the Ethnography of Transnational Law', (2006) 31 Law \& Social Inquiry 975-995; Paul Schiff Berman, 'The New Legal Pluralism', (2009) Annual Review of Law and Social Sciences 225-242

${ }^{44}$ Craig M. Scott, 'Introduction to Torture as Tort: From Sudan to Canada to Somalia', in Craig M. Scott (ed) Torture as Tort (2001); Harold Hongju Koh, 'Transnational Legal Process', (1996) 75 Nebraska Law Review 181-206

45 Craig M. Scott, "Transnational Law' as Proto-Concept: Three Conceptions', (2009) 10 German Law Journal 859-876; Peer Zumbansen, 'Transnational Law', in Peer Zumbansen (ed) Encyclopedia of Comparative Law (2006)
} 
norm creation which occurs outside of the state's law-making apparatus ${ }^{46}$, the other one connected to a particular understanding of law's relation to society. From this point of view, law is a particular form of societal communication, as such contributing to the overall totality of society, but not occupying a privileged or hierarchically superior vantage point. This approach which is most closely associated with the systems theory account of society developed by the late German sociologist, Niklas Luhmann, posits society as one 'without centre or apex'. ${ }^{47}$ In such a society, the state represents a particularly emblematic form of political organization the emergence (and fate) of which is historically embedded and thus contingent. That the centre (or, the pinnacle) of societies should be occupied by the state is - thus - both historically and geographically variable.

This has considerable consequences for an understanding of law. While Western legal thought has over a considerable time span learned to associate law with the state $^{48}$, it is by omission and a narrowing of one's gaze, that this nexus came to be universalized. ${ }^{49}$ Today's interest in 'law and globalization'50 should thus be seen as a welcome and most timely return to insights into the legal pluralist nature of law, which legal sociologists and anthropologists purported already a long time ago. ${ }^{51}$ Aiming for an understanding of society today through legal lenses, then, might prove a productive approach, as law can be seen as reflecting the changing structure of society. ${ }^{52}$ The crucial step, which can be made at this point, is to perceive of society as one in which many communicative forms and rationalities come together, and thus as a society in which states are but historically and geographically identifiable emanations of political organization. This opens an important vista on the 'history', the 'histories' and the 'non-history' of the state ${ }^{53}$, while it allows us to conceive of

46 Sally Engle Merry, 'Legal Pluralism', (1988) 22 Law \& Society Review 869-901; Marc Galanter, 'Farther Along', (1999) 33 Law \& Society Review 1113-1123

${ }^{47}$ Niklas Luhmann, Political Theory in the Welfare State [1981, transl. by John Bednarz Jr.] (1990)

${ }^{48}$ Max Weber, On Law in Economy and Society (transl. from the German Wirtschaft und Gesellschaft, 2nd ed., 1925, by E.Shils and M.Rheinstein, edited/annotated by M.Rheinstein) (1967)

${ }^{49}$ Andreas Fischer-Lescano/Gunther Teubner, 'Regime-Collisions: The Vain Search for Legal Unity in the Fragmentation of Global Law', (2004) 25 Michigan Journal of International Law 999-1046; see already Adda B. Bozeman, The Future of Law in a Multicultural World (1971), ix, “...biased in favor of the assumption that differences between cultures and political systems are functions primarily of different modes of perceiving and evaluating reality."

${ }^{50}$ An excellent overview is given by Paul Schiff Berman, 'From International Law to Law and Globalization', (2005) 43 Columbia Journal of Transnational Law 485-556.

51 Eugen Ehrlich, Fundamental Principles of the Sociology of Law (orig. published in German as Grundlegung der Soziologie des Rechts, 1913) (1962); Sally Falk Moore, 'Law and Social Change: the semi-autonomous field as an appropriate subject of study', (1973) 7 Law \& Society Review 719-746; Harry W. Arthurs, Without the Law: Administrative Justice and Legal Pluralism in Nineteenth Century England (1988)

52 Niklas Luhmann, A Sociological Theory of Law (1985)

53 Florian F. Hoffmann, 'In Quite a State: Trials and Tribulations of an Old Concept in New Times', in Florian F. Hoffmann (ed) Progress in International Law (2008) 
society as 'world society'. ${ }^{4}$ Understood in this vein, society becomes the backdrop and context for our iterations of law and, by consequence, for all ensuing attempts to engage in any form of comparative law. While it is true that "[C]onstitutions are made and then interpreted in complex and distinctive historical contexts"55, comparative law in a pluralistic world society ${ }^{56}$ forms the larger context for any attempt to identify and isolate constitutional typologies.

But, here is the moment where we need to pause. This is required if only to take appropriate notice of the considerable anxieties that accompany today's assertions of a world society, of global governance or global constitutionalism. ${ }^{57}$ How have we arrived at this point? Much suggests, that - at least in the West - a pertinent obsession with the state lies at the root of the alluded-to globalization anxiety, an anxiety that might at least be partially abated through the insistence on constitutional comparisons. For, the very possibility of such comparison would allow a return, as it were, to known demarcations and confined realms of societal, political and legal order.

Such realms, however, are always in motion. A categorization of constitutional qualities and characteristics and the complementing mapping of their distribution across time and space must therefore take into account, that historical and presentday depictions of this or that constitutional order are placed in a discursive field. In other words, rather than 'going out to see', comparative constitutionalism is confronted with and engaged in a discursive struggle of contentious statements about the political order at a given time. This has long preoccupied scholars of comparative political thought, an area which underlies and informs much of comparative constitutionalism today. At the centre of such work we find efforts to adequately identify, to interpret and label instantiations of 'change'. Bearing the problem of bias and viewpoint in mind, that we are likely only seeing what we set out to see ${ }^{58}$, any act of comparison continues to be haunted by grave doubts as to perception and method. ${ }^{59}$ At the same time, the very dynamic of societal change itself seems to resist any comparative assessment, if not undertaken 'from within',

\footnotetext{
${ }^{54}$ Niklas Luhmann, 'The World Society as a Social System', (1982) 8 International Journal of General Systems 131-138; John W. Meyer/John Boli/George M. Thomas/Francisco O. Ramirez, 'World Society and the Nation-State', (1997) 103 American Journal of Sociology 144-181

55 Vicki C. Jackson, 'Methodological Challenges in Comparative Constitutional Law', (2010) 28 Penn State International Law Review 319-326, 324

${ }^{56}$ Michel Rosenfeld, 'Rethinking constitutional ordering in an era of legal and ideological pluralism', (2008) 6 International Journal of Constitutional Law 415-455

${ }^{57}$ For a discussion of the 'four 'i's' (inappropriate, inconceivable, improbable or illegitimate), see Neil Walker, 'Taking Constitutionalism Beyond the State', (2008) 56 Political Studies 519-543, 520-25.

58 Poignantly depicted by Jonathan Hill, 'Comparative Law, Law Reform and Legal Theory', (1989) 9 Oxford Journal of Legal Studies 101-115.

${ }^{59}$ Ralf Michaels, 'The Functional Method in Comparative Law', in Ralf Michaels (ed) Oxford Handbook of Comparative Law (2006)
} 
that is on the grounds of a solid understanding of 'the times' and informed by an adequately sophisticated theory of society. Hence, the proximity of constitutional studies and historical political analysis, as illustrated by early 'comparativists' such as Montesquieu, Burke or Tocqueville. ${ }^{60}$

While the attempt to discern architectural determinants, frameworks and patterns of politico-constitutional organization is central to the comparative study of constitutional laws, the underlying motivations differ significantly. While for some the 'functional' comparison of working legal institutions and structures is at the forefront of the comparative enterprise, others pursue a discernibly more normative agenda. ${ }^{61}$ And yet, the overlapping of political and constitutional analytical lenses can easily blur the lines between universalist and functionalist analysis ${ }^{62}$, and it is under our very eyes that the studied legal culture dissolves into a dizzying map of ambiguous assertions and directions. Yet, as we have learned, historical change does not reveal itself 'as such', offering itself for straight-forward analysis and 'lessondrawing': rather, the experience of 'progress' is one of a future coming upon 'us' with accelerated velocity and unknown quality. ${ }^{63}$

Constitutions, we learn, fall with and rise from events of political tumult and overturn. 'Revolutions', then, can be read either to confirm the longest-established, but not materialized freedoms or to bring about the death of those wrong forms of liberty existing at the time. 'The very idea of the fabrication of a new government', noted Edmund Burke in his Reflections on the French Revolution, 'is enough to fill us with disgust and horror. We wished at the period of the Revolution, and do now wish, to derive all we possess as an inheritance from our forefathers. ${ }^{64}$ In this context, Burke famously posits that ' $[\mathrm{t}]$ he institutions of policy, the goods of fortune, the gifts of Providence, are handed down, to us and from us, in the same course and order. Our political system is placed in just correspondence and symmetry with the order of the world, and with the mode of existence decreed to a permanent body composed of transitory parts; wherein, by the disposition of a stupendous wisdom, moulding together the great mysterious incorporation of the human race, the whole, at one time, is never old, or middle-aged, or young, but in a condition of unchangeable constancy, moves on through the varied tenour of perpetual decay,

\footnotetext{
${ }^{60}$ Alexandre Tocqueville, Democracy in America (H.Reeve transl) [1835] (2000)

${ }^{61}$ David M. Beatty, The Ultimate Rule of Law (2004)

62 Mauro Cappelletti/William Cohen, Comparative Constitutional Law (1979); Durga Das Basu, Comparative Constitutional Law (1984); Konrad Zweigert/Hein Kötz, An Introduction to Comparative Law, 3rd ed. (1996)

${ }^{63}$ Reinhart Koselleck, 'Modernity and the Planes of Historicity (orig. in German, 1979, Vergangene Zukunft der frühen Neuzeit)', (1981) 10 Economy and Society 166-183, cited after Koselleck, Futures Past. On the Semantics of Historical Time (Keith Tribe transl., 2004), 9, 22.
}

${ }^{64}$ Cited in J.G.A. Pocock, 'Burke and the Ancient Constitution: A Problem in the History of Ideas', (1989) J.G.A. Pocock, Politics, Language \& Time. Essays on Political Thought and History 202-232, 205 
fall, renovation and progression. ${ }^{65}$ As noted by JGA Pocock in his discussion of Burke, 'The history of ideas may legitimately, though not exclusively, be viewed as the history of the modes of explaining the world and its behaviour which have from time to time existed."66 In this context Reinhart Koselleck remarked that the notion of revolution, which was first 'derived form the natural movement of the stars and thus introduced into the natural rhythm of history as a cyclical metaphor, henceforth attained an irreversible direction. It appears to unchain a yearned-for future while the nature of this future robs the present of materiality and actuality..."67 "To the extent that the past can be experienced only insofar as it contains an element of what is to come (and vice versa), the political existence of the state remains trapped within a temporal structure that can be understood as static mobility." 68

This is an observation of crucial importance for the purpose of the task here at hand. As aptly presented by the historians of political ideas and semantics, the discursive context in which the depiction of the meaning of revolution occurs is but all decisive. It is the eternal, immovable, inscrutable nature of the state as an all-encompassing entity and sphere, which appears to underlie and to inform the understanding of the revolution and of the political order which it brings into view. As the anchoring point for the liberties of those living within its confines, the state is indeed placed above the political order to which - in modern political parlance - it adheres to. Whether or not the state can in fact predate and precede the very idea of a certain political order, becomes irrelevant in the moment in which the state is seen to become the personification of a longstanding, historically evolved political order. The state now becomes - because it arguably has been - the guardian of liberties, and as such the representation of the constitutional order. 69

The state/constitutional order nexus would later become deeply steeped in a positivist depiction of the nature of the legal order itself. ${ }^{70}$ Associated with the state, the constitutional order becomes a product emitted from and depending on the state. $^{71}$ From this perspective, comparative constitutionalism would thus be an exercise in comparing state legal orders with a particular focus on the regulation of

\footnotetext{
${ }^{65}$ Cited in Pocock, preceding note, 211

66 Pocock, 'Burke and the Ancient Constitution', 204-5

${ }^{67}$ Koselleck, supra, at 23

${ }^{68}$ Koselleck, supra, at 22

${ }^{69}$ Pocock, note 3,212

${ }^{70}$ Dieter Grimm, 'Der Wandel der Staatsaufgaben und die Zukunft der Verfassung', in Dieter Grimm (ed) Staatsaufgaben (1996)

${ }^{71}$ Neil Walker, 'Taking Constitutionalism Beyond the State', (2008) 56 Political Studies 519-543, 521: "The invocation of the ideas and practices of constitutionalism involves a distinctive way of thinking about the world - an epistemic horizon and political imaginary that presupposes and refers to the particular form of the state."
} 
fundamental liberties. A quest for typologies and 'differences across systems' seems to suggest the continuation of this precise inquiry. But, is it still adequate?

\section{The Influence of Transnational Law on Comparative Constitutional Law}

There is today prolific evidence of comparative constitutional studies 'in action', as courts around the world - with differing degrees of deference ${ }^{72}$ - consider drawing on alternative, 'foreign' viewpoints in preparing and rendering their decisions. ${ }^{73}$ This view of 'foreign' constitutional law as both a guidance to local decision-making and as a 'work of art'74 has been subject of significant development and change. The causes of such change, in turn, may be identified as mainly originating out of two core developments: one is the fundamental transformation of what we might want to call the reference space for comparative constitutional law. The renewed advent of globalization in the twentieth century ${ }^{75}$ is marked by a far-reaching change in the position and status of states and sovereign political actors. The rise in importance of regional associations such as the European Union from its beginnings in the postWW II era to its present form (and woes) at the beginning of the twenty-first century echoes the complexity of transformation that - in admittedly decentralizing direction - the former Soviet Union has undergone over the last thirty years or so. ${ }^{76}$ The changes brought about for statehood since the second World War, through decolonization and regionalization, reunification and emancipation ${ }^{77}$ have drastically changed the anchoring and reference points for comparative

\footnotetext{
${ }^{72}$ Consider the 'controversy over citation', Dorsen et al, supra, $6 \mathrm{ff}$; see also the discussion of the 'living constitution' and the 'constitution as living tree' metaphors in Vicki C. Jackson, 'Constitutions as 'Living Trees'? Comparative Constitutional Law and Interpretive Metaphors', (2006) 75 Fordham Law Review 921-960, $941 \mathrm{ff}$.

${ }^{73}$ Lawrence v. Texas, 123 S. Ct. 2472, 2481 (2003); Ruti Teitel, 'Comparative Constitutional Law in a Global Age', (2004) 117 Harvard Law Review 2570-2596; for a skeptical view: Christopher McCrudden, 'A Common Law of Human Rights? Transnational Judicial Conversations on Constitutional Rights', (2000) 20 Oxford Journal of Legal Studies 499-532.

${ }^{74}$ Alexandra Kemmerer, 'Constitutional Law as Work of Art - Experts' Eyes: Judges of the World Examine the Constitution of Europe', (2003) 4 German Law Journal 859-862

75 Kevin H. O'Rourke/Jeffrey G. Williamson, Globalization and History. The Evolution of a NineteenthCentury Atlantic Economy (1999); Jürgen Osterhammel/Niels P. Petersson, Globalization: A Short History (2004)

${ }^{76}$ See András Sajó, Limiting Government. An Introduction to Constitutionalism (1999); Alexander Somek, 'Constitutionalization and the Common Good', paper for the Cardozo-NYU I-CON Colloquium, February 2010, on file with author.

${ }^{77}$ Craig Scott/Peer Zumbansen, 'Foreword: Making a Case for Comparative Constitutionalism and Transnational Law', (2006) 46 Osgoode Hall Law Journal vii-xix; Michel Rosenfeld, 'Rethinking constitutional ordering in an era of legal and ideological pluralism', (2008) 6 International Journal of Constitutional Law 415-455; Timothy Brennan, 'Postcolonial Studies and Globalization Theory', in Timothy Brennan (ed) The Post-Colonial and the Global (2008), 37 ff, 39, highlighting the normative bias of modern globalization writing: "The 'now' is the new, and the new is rapturously and exuberantly embraced."
} 
constitutional studies: "The transformation of statehood shatters the former unity of territory, power, and people, and challenges the constitution's ability comprehensively to encompass the political entity of the state."78 From the perspective, then, of the constitution's close association of the constitution and constitutionalism with the state, the prospects of comparative constitutional law seem to be tightly connected to the fate of comparative law in a globalized world, where the contours of statehood have become porous. ${ }^{79}$ Arguably, the relevance of the concept of 'constitutionalism' - as opposed to 'constitution' lies in its potential to build bridges between the constitutional law discourses within the nation state and the investigations into legitimacy of global governance in the 'post-national constellation'. 80

At the same time, the diminishing effect of constitutions on the global plane and the rise in importance of a rights- and entitlements-based concept of constitutionalism and constitutionalization for transnational human conduct give considerable cause of concern. The 'emergence of private authority in global governance' 81 - as expressed in areas such as trade agreements ${ }^{82}$, rating agencies ${ }^{83}$, product safety ${ }^{84}$, standardization ${ }^{85}$ or the lex mercatoria ${ }^{86}$ - constitutes a significant challenge for constitutional thought. These regulatory regimes in the transnational arena reflect, on the one hand, on a fundamentally changed role of the state in the exercise of 'public' governance ${ }^{87}$, the origins of which have to be seen, firstly, in a

78 Petra Dobner, 'More Law, less Democracy? Democracy and Transnational Constitutionalism', in Petra Dobner (ed) The Twilight of Constitutionalism? (2010), 141.

${ }^{79}$ David Kennedy, 'New Approaches to Comparative Law: Comparativism and International Governance', (1997) Utah Law Review 545-637; Christopher A. Whytock, 'Taking Causality Seriously in Comparative Constitutional Law: Insights from Comparative Politics and Comparative Political Economy', (2008) 41 Loyola of Los Angeles Law Review 629-682

80 Jürgen Habermas, The Postnational Constellation (2001); Jürgen Habermas, 'A Political Constitution for the Pluralist World Society?' in Jürgen Habermas (ed) Between Naturalism and Religion.

Philosophical Essays (2008)

${ }^{81}$ R. Hall/T. Biersteker (eds), The Emergence of Private Authority: Form of Private Authority and their Implications for International Governance (2001)

82 David Schneiderman, 'Investment Rules and the New Constitutionalism', (2000) 25 Law \& Soc Inquiry 757-783

83 Timothy J. Sinclair, 'Passing Judgment: Credit Rating Processes as Regulatory Mechanisms of Governance in the Emerging World Order', (1994) 1 Review of International Political Economy 133159; Dieter Kerwer, 'Holding Global Regulators Accountable: The Case of Credit Rating Agencies', (2005a) 18 Governance 453-475

${ }^{84}$ Harm Schepel, The Constitution of Private Governance. Product Standards in the Regulation of Integrating Markets (2005)

85 Nils Brunsson/Bengt Jacobsson, A World of Standards (2000)

86 A. Claire Cutler, Private Power and Global Authority: Transnational Merchant Law in the Global Economy (2003)

${ }^{87}$ Armin Bogdandy/Philipp Dann/Matthias Goldmann, 'Developing the Publicness of Public International Law', (2008) 9 German Law Journal 1375-1400 
transformation of the inter-national context ${ }^{88}$ and in the inner-state shift 'from government to governance'. ${ }^{89}$ Secondly, these changes are associated with the emergence of norm-making processes, institutions of rule creation, as well as implementation and adjudication which scholars are struggling to re-categorize. Negotiating their allegedly 'autonomous' nature 90 'without' 91 or 'beyond' 92 the state, lawyers, political philosophers and sociologists are equally faced with the following question: "Is constitutional theory able to generalize the ideas it developed for the nation state and to re-specify them for today's problems? In other words, can we make the tradition of nation-state constitutionalism fruitful and redesign it in order to cope with phenomena of privatization and globalization?"93

The present inquiry unfolds against the background of the two contexts of transformation - the international and the national one. That the field of comparative (constitutional) law, despite pertinent enterprises to scrutinize its methodological foundations ${ }^{94}$, still lacks satisfactory theoretization, has been remarked by scholars all around. ${ }^{95}$ More importantly and substantively more fruitfully, scholars have highlighted the importance of a forceful engagement with the methodological challenges arising from any comparative legal project today. ${ }^{96}$

\footnotetext{
${ }^{88}$ See eg Robert 0. Keohane/Joseph S. Nye, 'Introduction', in Robert O. Keohane/Joseph S. Nye (eds), Governance in a Globalizing World (2000), Myres S. McDougal/W. Michael Reisman, 'The World Constitutive Process of Authoritative Decision', in Myres S. McDougal/W. Michael Reisman (eds), International Law Essays (1981) and John M. Hobson, The State and International Relations (2000).
}

${ }^{89}$ Mark Bevir/R.A.W. Rhodes/Patrick Weller, 'Traditions of Governance: Interpreting the Changing Role of the Public Sector', (2003) 81 Public Administration 1-17; Alfred Aman Jr., 'Law, Markets and Democracy: A Role for Law in the Neo-Liberal State', (2007) 51 New York Law School Review 801815; Rod A. W. Rhodes, 'Waves of Governance', in Rod A. W. Rhodes (ed) Oxford Handbook of Governance (2011)

${ }^{90}$ Berthold Goldman, 'Frontières du droit et 'lex mercatoria", (1964) 13 Archives de la Philosophie de Droit 177-192; Klaus Peter Berger (ed) The Practice of Transnational Law (2001); for a critique, see Thomas Schultz, 'Some Critical Comments on the Juridicity of Lex Mercatoria', (2008) X Yearbook of Private International Law 667-710; Peer Zumbansen, 'Piercing the Legal Veil: Commercial Arbitration and Transnational Law', (2002) 8 European Law Journal 400-432; Gralf-Peter Calliess/Peer Zumbansen, Rough Consensus and Running Code: A Theory of Transnational Private Law (2010).

${ }^{91}$ Gunther Teubner, "Global Bukowina': Legal Pluralism in the World Society', in Gunther Teubner (ed) Global Law Without A State (1997)

92 Ralf Michaels, 'The True New Lex Mercatoria: Law Beyond the State', (2007) 14 Indiana Journal of Global Legal Studies 447-468

${ }^{93}$ Gunther Teubner, 'Fragmented Foundations: Societal Constitutionalism beyond the Nation State', in Gunther Teubner (ed) The Twilight of Constitutionalism? (2010), 328.

${ }^{94}$ H. Patrick Glenn, 'Comparative Legal Families and Comparative Legal Traditions', in H. Patrick Glenn (ed) Oxford Handbook of Comparative Law (2006), and Professor Glenn's groundbreaking textbook, soon to be published in its fifth edition.

95 Ran Hirschl, 'The Question of Case Selection in Comparative Constitutional Law', (2005) 53 American Journal of Comparative Law 125-155 
The present article embraces these insights and highlights, in particular, the importance of treating both terms - transnational and constitutionalism - as unknowns, as terms that need to be unfolded in order to gain a better understanding of their traction today.

\section{Constitutionalism in World Society: post-national, post-territory, post- state?}

Sociologists have long emphasized the need to conceive of society as a functionally differentiated, highly complex set of communications and processes. ${ }^{97}$ In that context, states would count less as instantiations of a territorially bounded, specifically peopled and governed space and, in turn, as natural reference points for (comparative) constitutional thought. Instead, the sociologist would see states with all of their characteristics as historically developed and particular embodiments of political power that can be found in different forms and shapes and at different times around the world and through time. While such time keeping has traditionally been seen to have begun in the seventeenth century with the creation of the 'Westphalian' order, it is the respective connotation of Westphalian statehood with ideas of law, rights, democracy on the one hand and with the concept of the constitution on the other, which has given rise to a number of contestations. First, the nexus between the state and a particular form of political and legal rule has been rejected as inadequately excluding alternative forms of political/legal organization from view..$^{98}$ Second, the focus on the state as the decisive organizing entity gives undue primacy to the political form of societal organization, thereby turning a blind eye to the manifold forms of societal order. ${ }^{99}$ Mirroring the constantly increasing level of differentiation in society as perceived as against the contingent yet pertinent background of particular local contexts, there is a rapidly expanding space of functional differentiation beyond the confines of the nation state. Security, the environment, financial organization or work have attained the status of complex regulatory and organizational spaces, the institutional and normative scope of

\footnotetext{
96 Russell A. Miller, 'Introduction', in Russell A. Miller (ed) Global Legal Traditions: Comparative Law in the Twenty-First Century (2011), who draws on Patrick Glenn's concept of legal traditions to argue that "the answer must be that legal tradition need not be the object of a comparative undertaking, but instead might be part of the inquiry to be made in better understanding the laws or legal institutions that eventually become the objects of comparison."

${ }^{97}$ Niklas Luhmann, 'Globalization or World Society: How to Conceive of Modern Society?' (1997) 7 Int'l Rev. Sociol. 67-79; John W. Meyer/John Boli/George M. Thomas/Francisco O. Ramirez, 'World Society and the Nation-State', (1997) 103 American Journal of Sociology 144-181

98 Eugen Ehrlich, Fundamental Principles of the Sociology of Law (orig. published in German as Grundlegung der Soziologie des Rechts, 1913) (1962), 465; Sally Engle Merry, 'Legal Pluralism', (1988) 22 Law \& Society Review 869-901; today: Gunther Teubner, 'Fragmented Foundations: Societal Constitutionalism beyond the Nation State', in Gunther Teubner (ed) The Twilight of Constitutionalism? (2010), 331.

${ }^{99}$ Sally Engle Merry, 'New Legal Realism and the Ethnography of Transnational Law', (2006) 31 Law \& Social Inquiry $975-995$
} 
which it is no longer possible to grasp through concepts of the state or through the nineteenth century distinction of 'state' and 'market'.100 Third, the focus on the Westphalian state as the prime entity of political organization has been accompanied by a connotation of sovereignty, which over time has become both decontextualized and ahistoricized. As a result, the present era of globalization is presented as an aberration, erosion and transformation of state sovereignty due to the perceived increased interdependence among states. This depiction, however, rests on a very partial representation of the international history to this day, a history which has been marked by a distinctly uneven distribution of political and economic powers.101 In turn, sovereignty, even when portrayed today as 'challenged' and 'transformed', for example by the rise in importance of non-state actors, claiming new subjectivity in international law ${ }^{102}$ or driving constitutional rights creation in parts of Asia ${ }^{103}$, still tends to hide the underlying dynamics of inclusion and exclusion, the stark divide between 'core' and 'periphery'104 and the persistent discrimination of the 'other'. 105

Apart from a radically relativized status of the state from the point of view of a world society concept, human relations are being considered in an entirely new light as well. In the eyes of the legal and political philosopher, the 'civil society subject' [bürgerliches Subjekt] at the beginning of the modern constitutional era, which morphed into the subject of the twentieth-century 'mass society' has meanwhile been replaced by today's 'cosmopolitan subject', which is "above all smart. It regards the world as resource for interesting projects." 106 But, this leaves little room - or need - for the capacity to political judgment, if the 'historical a priori is not a communal space encompassed by the state, but functionally differentiated, transnational problem solving processes."107

100 Helmut Willke, Smart Governance. Governing the Global Knowledge Society (2007), 53

101 Antony Anghie, 'The Evolution of International Law: colonial and postcolonial realities', (2006) 27

Third World Quarterly 739-753; B.S. Chimni, 'Third World Approaches to International Law: A

Manifesto', (2006) 8 International Community Law Review 3-27

102 Philip Alston, 'The 'Not-a-Cat' Syndrome: Can the International Human Rights Regime

Accommodate Non-State Actors?' in Philip Alston (ed) Non-State Actors and Human Rights (2005)

103 Wen-Chen Chang, 'An Isolated Nation with Global-Minded Citizens: Bottom-Up Transnational Constitutionalism in Taiwan', (2009) 4 National Taiwan University Law Review 203-235, 222-230

104 Boaventura de Sousa Santos, 'The World Social Forum and the Global Left', (2008) 36 Politics \& Society 247-270

105 Diane Otto, 'Lost in translation: re-scripting the sexed subjects of international human rights law', in Diane Otto (ed) International Law and its Others (2006)

106 Alexander Somek, 'Die Verfassung im Zeitalter ihrer transnationalen Reproduzierbarkeit. Gedanken zum Begriff der Konstitutionalisierung', in Alexander Somek (ed) Strukturfragen der Europäischen Union (2011), 141

107 Id., at 142 
And the sociologists and philosophers of the risk society, which now spans the globe ${ }^{108}$, observe, that "[e]verybody, whether they want it or not, is shaped by the individualism and rationality of a single global culture which includes human rights culture as well as the culture of individualized suicide bombing. All cultural differences are now in the same society and of individualized persons who have to organize and reorganize, construct and reconstruct their ego and their personal and collective identity lifelong, and in order to do that they rely only on the (weak or strong) means of their own autonomy." [...] Yet, as 'free men' we are not looking with Sartre into the abyss of nothingness, but are acting against a dense and common background of relatively abstract, highly general and formal, thoroughly secular, nevertheless global knowledge that is implicit in the global social life-world. This is so simply because traditional identity formations no longer and nowhere are available without a permanently growing and changing variety of alternative offers, in Teheran as well as in New York, in the Alps of Switzerland as well as in the mountain regions of Afghanistan, Pakistan, or Tibet."109

Comparative constitutional law scholars, hence, face a conundrum. Where they turn towards states in the international arena in order to depict particular types and forms of constitutional order, they find themselves in a 'new world'. Searching for institutional familiarity or, at least, complementarity, they are increasingly faced with the fluidity of the institutional and procedural frameworks that so far marked the anchor points for comparison, something which has been guiding the Canadian comparativist H.Patrick Glenn in his refutation of comparative studies that aim at circumscribing 'systems' through the association with static and fixed boundaries. ${ }^{110}$ It also inspires the ambitious project of a transnational group of constitutional scholars in their effort to explore the openness of 'global legal traditions'.111 The changed transnational landscape, then, reflects a distinct transnationalization in the form of an emerging multilevel constitutional universe ${ }^{112}$ pushing for an openended reconfiguration of constitutional and interpretative competences. An American court wishing to engage with the constitutional law of, say, France or Germany, will - despite a good understanding of the particular nature of

108 Ulrich Beck, World at Risk [orig. German "Weltrisikogesellschaft" (Frankfurt: Suhrkamp); Ciaran Cronin, transl.] (2009)

${ }^{109}$ Hauke Brunkhorst, 'Constitutionalism and Democracy in the World Society', in Hauke Brunkhorst (ed) The Twilight of Constitutionalism? (2010), 186-7.

${ }^{110}$ H. Patrick Glenn, Legal Traditions of the World: Sustainable Diversity in Law [2000] 2nd ed. (2004)

111 An-Naim et al, Global Legal Traditions: Comparative Law in the Twenty-First Century, forthcoming, 2012.

112 Christian Tomuschat, 'The Effects of the Judgments of the European Court of Human Rights According to the German Constitutional Court', (2010) 11 German Law Journal 513-526; Norman Dorsen/Michel Rosenfeld/András Sajó/Susanne Baer, Comparative Constitutionalism. Cases and Materials. 2nd ed. (2010), 77 ff ('The Transnational Constitution') 
constitutional review in both countries ${ }^{113}$ - find itself confronted with the European Court of Human Rights' effect on what has long become a complex interplay of different levels of norm-creation and compliance. ${ }^{14}$

Substantively, this altered landscape appears to elude claims of deliberation, reciprocity and 'engagement' as risk management, 'hedging' and knowledge-driven assessments assume the dominant places in societal providence. Faced with this 'mismatch between societal complexities and the means and modes of governance'115 the constitutionalist is prompted to reconsider her perspectives and options. ${ }^{116}$ It is thus not surprising, that comparative law scholars, in the light of the porous confines of national constitutional orders, have been directing their view towards differently construed architectures of constitutional ordering. This is aptly reflected in the emergence of comparative constitutionalism ${ }^{117}$, reflected today, for instance, in vibrant discourses around the 'migration' of constitutional ideas ${ }^{118}$ and 'transnational constitutionalism'. ${ }^{119}$ Yet -despite the intensity of such endeavors - it still appears as if "[c]onstitutionalism is one of those concepts, evocative and persuasive in its connotations yet cloudy in its analytic and descriptive content, which at once enrich and confuse political discourse". ${ }^{120}$

Accordingly, an inquiry into the methodological foundations of comparative constitutional law cannot avoid a serious engagement with the conceptual aspirations of constitutionalism. As will become evident in the remainder of this article, such an engagement first requires a series of clarifications and demarcations, precisely because on both sides, with comparative constitutional law on the one end and constitutionalism on the other, in view of the elements of a theoretical groundwork and of a conceptual architecture that require being unpacked in their own right. In other words, the seemingly more clearly circumscribed walls of

\footnotetext{
113 Wolfgang Hoffmann-Riem, 'Two Hundred Years of Marbury v. Madison: The Struggle for Judicial Review of Constitutional Questions in the United States and Europe', (2004) 5 German Law Journal 685-709

${ }^{114}$ Christian Tomuschat, 'The Effects of the Judgments of the European Court of Human Rights According to the German Constitutional Court', (2010) 11 German Law Journal 513-526

115 Helmut Willke, Smart Governance. Governing the Global Knowledge Society (2007), 39

116 Abdullah Ahmed An-Na'im, Islam and the Secular State. Negotiating the Future of Shari'a (2008), $84 \mathrm{ff}$ (ch. 3)

117 Norman Dorsen/Michel Rosenfeld/András Sajó/Susanne Baer, Comparative Constitutionalism. Cases and Materials. 2nd ed. (2010)

118 Sujit Choudhry (ed) The Migration of Constitutional Ideas (2006)

${ }^{119}$ Excellent: Petra Dobner, 'More Law, less Democracy? Democracy and Transnational Constitutionalism', in Petra Dobner (ed) The Twilight of Constitutionalism? (2010), and Neil Walker, 'Taking Constitutionalism Beyond the State', (2008) 56 Political Studies 519-543, $525 \mathrm{ff}$.
}

120 Thomas C. Grey, 'Constitutionalism: An Analytic Framework', in Thomas C. Grey (ed) Constitutionalism [NOMOS XX. Yearbook of the American Society for Political and Legal Philosophy] (1979), 189. 
comparative constitutional law when contrasted with the more ambiguous sounding term of 'constitutionalism' emerge as much less sharply accentuated in light of the fundamental methodological qualms that comparative law as such has forever been burdened with. Added to these aches, comparative constitutional law faces deep-reaching questions regarding the employed concepts, histories and assumptions surrounding its proper subject - the constitution. It is here, where constitutionalism can be seen as opening up perspectives for comparative constitutional law as an area of legal scholarship towards alternative and complementing forms of structuring societal orders with collectively binding effects. But, defining constitutionalism in distinction from comparative constitutional law hardly exhausts the conceptual potential of the term. Instead, what becomes apparent when tracking the various contexts in which scholars have been studying constitutionalism, is that the term has a life beyond being a term that transcends the confines of comparative constitutional law.

It is at this point that we begin to recognize most clearly how the emerging, productive tension between the two poles in fact illustrates in exemplary fashion the conundrical relation between law and society. Against the background of the sociological description of a highly differentiated world risk society alluded to above, the tension between comparative constitutional law and constitutionalism gives expression to law's struggle to respond to this growing complexity. Law's 'lagging behind' society's evolution is a longstanding observation made by legal sociologists ${ }^{121}$, but it receives a particular twist in the subject area we are here concerned with. The recognition of a 'world risk society'122 points to farreaching consequences for legal theory, which has to assert itself in this changed reference context. $^{123}$ For comparative constitutional law, productively challenged by constitutionalism, the sociological account of a world risk society prompts a fundamental critique of this area of law's starting assumptions as to its institutional and normative basis. And it is from this perspective, that we see comparative constitutional law/constitutionalism as a sharp lens to track law's role in giving a legal voice to myriad expressions of societal differentiation. To the degree that comparative constitutional law would focus on more or less easily recognizable structures and processes of 'constitutional' acts, norm creation and adjudication, constitutionalism - by contrast - would reach deep into the less obvious places where collectively binding order emerges. From this angle, constitutionalism allows us to draw on the legal pluralist insights, which emerged in the 1960 s and $1970 \mathrm{~s}^{124}$ and which today immensely enrich our inquiry into the evolving regulatory, hybrid,

\footnotetext{
121 See, eg, Niklas Luhmann, A Sociological Theory of Law (1985).

122 Ulrich Beck, 'Living in the world risk society', (2006) 35 Economy and Society 329-345

123 Marc Amstutz, 'The Letter of the Law: Legal Reasoning in a Societal Perspective', (2009) 10 German Law Journal 361-382

${ }^{124}$ Sally Falk Moore, 'Law and Social Change: the semi-autonomous field as an appropriate subject of study', (1973) 7 Law \& Society Review 719-746; Marc Galanter, 'Why the 'Haves' Come Out Ahead: Speculations on the Limits of Legal Change', (1974) 9 Law \& Society Review 95-160
} 
public-private and national/international landscape. ${ }^{125}$ This enrichment occurs in several dimensions that are relevant for an adequate appreciation of constitutionalism in the here argued sense. One such dimension concerns the emphasis on the intricacies and pluralities of social ordering mechanisms, the legal nature of which legal pluralists, greatly aided by anthropology, have been directing our attention to - not least in the area of human rights law.126 Another dimension embraces 'the critical/emancipatory aspects of investigating into the ambiguous nature of norms and their protective scope. Again, human rights are of central relevance, but now seen from a political economy perspective, from which we learn to carve out human rights dimensions in social and economic rights that are otherwise only associated with market functions. ${ }^{127}$ This approach has been central to the rich body of work around the law of the welfare state and its evolution. ${ }^{128}$ In short, I am conceiving of constitutionalism as being, on the one hand, an emblematic expression of the need to reconsider one's methodological starting point with regard to the structure and nature of the evolving regulatory landscape, which is importantly characterized by an intertwining and overlapping of norms of both public and private, national and international origin. On the other hand, constitutionalism captures the attempt to engage in a critical reading of law and governance that tries to look beyond traditional concepts of legal authority and public versus private spaces of norm creation.

The transnational transformation of international political sovereignty is characterised by the overlap and the intersection of historical associations of nineteenth century governmental design and liberal political theory on the one hand and the insight into the tedious tension between legislative prerogatives and fundamental rights on the other. ${ }^{129}$ Constitutionalism unties the nexus between

\footnotetext{
125 Sally Engle Merry, 'Anthropology, Law, and Transnational Processes', (1992) 21 Annual Review of Anthropology 357-379; Peer Zumbansen, 'Transnational Legal Pluralism', (2010) 1 Transnational Legal Theory 141-189 (http://ssrn.com/abstract=1542907)

${ }^{126}$ See, eg, Richard Ashby Wilson, 'Tyrannosaurus Lex: The Anthropology of Human Rights and Transnational Law', in Richard Ashby Wilson (ed) The Practice of Human Rights: Tracking Law Between the Global and the Local (2006).

127 See, eg, Crawford Brough Macpherson, 'The Rise and Fall of Economic Justice', (1987) in: Macpherson, The Rise and Fall of Economic Justice, and other Essays. The role of state, class and property in twentieth-century democracy 1-20.

128 Rudolf Wiethölter, 'Social Science Models in Economic Law', in Rudolf Wiethölter (ed) Contract and Organisation. Legal Analysis in the Light of Economic and Social Theory (1986); for a perspective after the 'rights revolution', see Cass Sunstein, After the Rights Revolution. Reconceiving of the Regulatory State (1990), and Orly Lobel, 'The Paradox of Extralegal Activism: Critical Legal Consciousness and Transformative Politics', (2007) 120 Harvard Law Review 937-988.

${ }^{129}$ Bruce A. Ackerman, 'The Storrs Lectures: Discovering the Constitution', (1984) 93 Yale Law Journal 1013-1072; Jürgen Habermas, 'On the Internal Relation between the Rule of Law and Democracy', (1995) 3 European Journal of Philosophy 12-20; Ronald Dworkin, 'Constitutionalism and Democracy', (1995) 3 European Journal of Philosophy 2-11; András Sajó, Limiting Government. An Introduction to Constitutionalism (1999), xiv.
} 
'state' and 'constitution' by positing an inner connection between the form and substance of government. ${ }^{130}$ In breaking down the complementary association between the state and the constitution, the concept of constitutionalism recreates opportunities to conceive of different foundations and ties of constitutional norms. Herein lies its great promise - and also its risk. Taking an optimistic view, constitutionalism can be seen as law's unveiling of its emancipatory potential: constitutionalism frees constitutional norm thinking from any given institutional framework and instead provides a space in which such a framework can or rather, must first be designed. From a more skeptical vista, however, the accompanying notions of 'limiting' government tend to propel a normative assessment of the state's 'proper business' rather than merely demarcating the extent of its regulatory arm. ${ }^{131}$ This focus on limiting, or placing constraints on government powers, has arguably been part of what scholars have referred to as 'traditional constitutionalism'. ${ }^{132}$

\section{Space}

This limiting function of constitutional frameworks has, as we saw, been a crucial element in the evolution of politico-constitutional theorizing. It comes as little surprise, then, that a certain 'gist' is attributed to this history. Harking back to canonical texts of comparative legal theory, the underlying assumption of progress, often coupled with a strong plea for progress ${ }^{133}$, continues to have a strong impulse for the recognition and elaboration of border-crossing normativity. But, in the transnational context, this implication of normative progress - allegedly expressed, for example, by (in the Western understanding) the 'progress' in human rights law $^{134}$, has tremendous consequences for a critique of emerging legal structures. In the heated discussion around an emerging 'global' legal order, two features in this context are particularly worthy of being highlighted. The first concerns the question of the connection between a global legal order and the domestic legal system. This

${ }^{130}$ Compare with Jeremy Waldron, 'Constitutionalism: A Skeptical View', (2010) New York University Public Law \& Legal Theory Research Paper No. 10-87 http://ssrn.com/abstract=1722771, 13: "Unlike, say, the Rule of Law, constitutionalism is not just a normative theory about the forms and procedures of governance. It is about controlling, limiting, and restraining the power of the state."

131 Jeremy Waldron, 'Constitutionalism: A Skeptical View', (2010) New York University Public Law \& Legal Theory Research Paper No. 10-87 http://ssrn.com/abstract=1722771, 17-8.

132 Jiunn-Rong Yeh, 'The Emergence of Asian Constitutionalism: Features in Comparison', (2009) 4 National Taiwan University Law Review 39-53, 41. Professor Yeh has argued that this type of constitutionalism has been succeeded by 'transitional constitutionalism', marked by a high degree of dynamic change, future empowerment and contingent constitutional arrangements, which are likely to be changed and adapted later. The last stage in this development he depicts as 'transnational constitutionalism', marked by the emergence of supra-national constitutional frameworks (for example the EU), the tension between 'domestic' and 'transnational' constitutional norms, and the increasing institutional borrowing and judicial dialogue. Id., at 44 .

133 Konrad Zweigert/Hein Kötz, An Introduction to Comparative Law, 3rd ed. (1996), 43 ff

${ }^{134}$ For a critique, see only Upendra Baxi, The Future of Human Rights (2002). 
question, then, turns on the degree of autonomy of one from the other. Arguably, claims of an emerging global legal order have been put forward precisely not only to illustrate the autonomy of global law from the (nation) state, but in addition to underscore the distinct nature of the emerging body and system of norms. ${ }^{135}$ The second strand in the cluster of arguments in favor of an emerging globality of law concerns the question of legitimacy. Here, again, the discussion has become considerably differentiated: while scholars in the context of assessing the prospects of public international law in the face of global terrorism, climate change and unilateralism, argue for the increasing materiality of constitutionalist thinking outside of the nation-state ${ }^{136}$, others have taken a closer look at the intersection between international law and political philosophy, scrutinizing the chances for a cosmopolitan legal order. ${ }^{137}$ It is within the larger debate about cosmopolitanism, that some of the longstanding challenges of constituting a pluralistic, democratic political order become visible and open to scrutiny - from the perspectives of law, philosophy and political science. What, on the one hand, differentiates but, on the other, also reconnects this strand of debate with the one focusing on global constitutionalism, is the distinct widening of the perspective from a predominantly legal inquiry towards one which places the constitution of a legal order within a comprehensive discussion of the legitimacy concerns of such an order. ${ }^{138}$ Finally, a third strand in the context of assessing the challenges of a global legal order, approaches the problem from a distinctly procedural angle. Arguing for the relevance of administrative law rules to further the legitimacy of global governance institutions, scholars in this field have been mobilizing the idea of a 'global administrative law'. ${ }^{139}$ Over the span of a few years, this research has met with farreaching attention, pressing for a further clarification and elaboration of central premises such as the comparative status of constitutional law concerns within the administrative governance orientation of the GAL project ${ }^{140}$ or the prospects of the concept of the Rule of Law within the continuing debate around the institutional and normative pillars of global governance. ${ }^{141}$

This differentiation of the debate around an emerging global legal order is, as we have seen, intimately tied into questions of boundaries and legal or, regulatory

\footnotetext{
135 Gunther Teubner, 'The King's Many Bodies: The Self-Deconstruction of Law's Hierarchy', (1997) 31 Law \& Society Review 763-787

136 Ackerman, 1997; St. John Macdonald \& Johnston eds., 2005

137 Kant 1795, Held 2005, Archibugie 2009

138 Bryde, in St John Macdonald \& Johnston eds., 2005; Kreide, 2009

139 Benedict Kingsbury/Nico Krisch/Richard Stewart, 'The Emergence of Global Administrative Law', (2005) 68 Law \& Contemporary Problems 15-61

140 Nico Krisch, 'Global Administrative Law and the Constitutional Ambition', (2009) LSE Law, Society and Economy Working Papers 10/2009 http://ssrn.com/abstract=1344788
}

141 Benedict Kingsbury, 'The Concept of 'Law' in Global Administrative Law', (2009) 20 Eur. J. Int'l L. 23-57 
'spaces' (national/domestic vs. 'global) on the one hand, and questions of legitimacy, accountability, representation, on the other. This overlapping of inquiries into the status and nature of the evolving legal order has been contributing to a further approximation of legal theoretical discourse and parallel scholarly pursuits in disciplines such as geography, sociology, anthropology. These disciplines have been of crucial importance in illuminating and emphasizing the methodological complexity of global governance discourses and are central to a redefinition of constitutionalism, as we will develop in greater detail in the concluding section. Meanwhile, they offer important echoes and re-instantiations of the type of questions raised by legal pluralists over the course of the $20^{\text {th }}$ century. Legal pluralism, arguably, has been concerned with critiquing the demarcation lines between 'official' and 'inofficial' rule systems, in other words with the identification and scrutinizing of the justifications offered to distinguish between law and 'nonlaw'.142 In the context of analyzing the nature of 'global law rules', the legal pluralists' interest in laying bare the political and ideological choices involved in differentiating spheres of rule-making proves to contribute a crucial perspective on the applied analytical lenses and methodological approaches. ${ }^{143}$

Against this background, it becomes questionable whether one may aptly characterize the just-mentioned approaches in studying global law as spatial. ${ }^{144}$ This adjective would be justified to the degree that the metaphor of space continues to function as a helpful tool for the identification of constituted spheres of rule creation, enforcement and political order. At the same time, it becomes less pervasive when applied in the context of an inquiry into the nature of evolving legal norms, that grow out of border-crossing, 'privatised' and transnational norm making processes. ${ }^{145}$ Space, then, ceases to demarcate an identiable, confined realm, rather than pointing to the ambiguity and relative openness of reasons given for the constitution of space this way or that.

Despite a well-reasoned skepticism towards the metaphor of space in understanding the 'location' of global law, legal scholars have been insisting on the

\footnotetext{
142 John Griffiths, 'What is Legal Pluralism?' (1986) 24 Journal of Legal Pluralism and Unofficial Law 155; Marc Galanter, 'Farther Along', (1999) 33 Law \& Society Review 1113-1123

143 Paul Schiff Berman, 'Global Legal Pluralism', (2007) 80 Southern California Law Review 11551237; Paul Schiff Berman, 'The New Legal Pluralism', (2009) Annual Review of Law and Social Sciences 225-242; Ralf Michaels, 'Global Legal Pluralism', (2009) Duke Public Law \& Legal Theory Research Paper No. 259 http://papers.ssrn.com/sol3/papers.cfm?abstract_id=1430395; Peer Zumbansen, 'Transnational Legal Pluralism', (2010) 1 Transnational Legal Theory 141-189 (http://ssrn.com/abstract=1542907)

${ }^{144}$ Saskia Sassen, 'The Places and Spaces of the Global: An Expanded Analytic Terrain', in Saskia Sassen (ed) Globalization Theory. Approaches and Controversies (2007); PhilippopoulosMihalopoulos, 2010

145 Colin Scott, 'Regulatory Governance and the Challenge of Constitutionalism', (2010) EUI Working Papers. Robert Schuman Centre for Advanced Studies, Private Regulation Series-02 http://ucdie.academia.edu/documents/0093/9406/RSCAS_2010_07.pdf
} 
continued importance of making spatial metaphors part of the legal methodological calculus in order to further scrutinize the challenges - and shortcomings - of spatial representations of legal normativity. ${ }^{146}$ From this perspective, references to space as well as to 'levels' of regulatory authority continue to be of central importance in the context of global governance analysis, even where they are explicitly contested. ${ }^{147}$ What should be retained, then, from this consideration of the significance of spatial metaphors in legal reasoning in the context of global governance, is the 'framing' nature of these metaphors in legal discourse. As impressively illustrated by the untiring inquiry into the promises and fallbacks of federalism, legal theory today can no longer confine itself to a juxtaposition of either-or choices, as between federalism or unity, regulatory competition or harmonization. The crux of these order paradigms lies in their inconclusiveness: just as a system arguably resting either on principles of horizontal unity and equity or of hierarchical supremacy, a federalist system does not offer - on its own - answers to questions touching on the substance of the regulatory issue to be decided. Hence, whether or not a regulatory challenge is a matter of federalism, does not carry any weight for the resolution of the underlying substantive issue (Rose-Ackerman). And yet, the existence or non-existence of a federal system (or, of a non-federalist one) has distinct consequences for the evolution and application of constitutional rules in a particular system (Howse \& Nicolaidis, 2001), which in turn is of relevance for the identification of comparative typologies.

\section{Time}

The spatial dimension of law, elaborated upon in the previous section, arguably is complemented by a temporal one. This dimension begins to unfold when one takes into consideration the transformation of the legal systems under comparison. Stark expressions of such transformations become visible, of course, in cases of dramatic regime and system change, for example at times of 'transitional jutice' or postconflict regime building. ${ }^{148}$ The transformation of a legal system, in such instances, is embedded in and inseparable from a much more comprehensive change of the political, socio-economic and even day-to-day system. ${ }^{149}$ As such, a legal system's history is always part of and tied into a significantly more complex history of change (Sarat). "The most salient feature of the post-colonial model is that both [...] the constitutional order and identity of the newly independent former-colony are elaborated in a dialectical process involving an ongoing struggle between

\footnotetext{
146 Marc Amstutz/Vaios Karavas, 'Weltrecht: Ein Derridasches Monster', in Marc Amstutz/Vaios Karavas (eds), Soziologische Jurisprudenz. Liber Amicorum für Gunther Teubner zum 65. Geburtstag (2009)

147 Twining, 2006; Blank, 2010

148 Inga Markovits, 'Selective Memory: How the Law Affects What We Remember and Forget from the Past: The Case of East Germany', (2001) 35 Law \& Society Review 513-563
}

149 Ruti Teitel, Transitional Justice (2000) 
absorption and rejection of the former colonizer's most salient relevant identities." 150

The consideration of change over time, however, still needs to take into view the contested nature of what comes into view, what lies at the surface and what is lurking in the background and underwood. As famously elaborated by Yerushalmi in his study of Jewish remembrance, a chronology of events is likely to be remembered as a chronology of experiences, the latter being both 'out of time' and yet embedded in a comprehensive narrative of collective identity. ${ }^{151}$ The post-conflict context evokes, to be sure, a set of comprehensive and intricate demarcations concerning the nature and quality of 'things changed'. While post-conflict, retroactive or transitional justice identify perspectives on legal and political regime change following a fundamental breakdown, rupture or decay of an existing order ${ }^{152}$, a wider perspective still would take into view the historical period in which the studied transformations occur. This certainly makes for an overwhelming panorama. Hence, the need to draw out the connections between the spatial and the temporal axis between which the present observations are being made. This 'reminder' of sorts, however, points to the considerable dilemma, which is underlying the task at hand. This dilemma results from the attempt to provide for a reasonable account of the evolution of political-constitutional structures, but there are non-negligible problems associated with such an undertaking.

\section{Governance in Space and Time}

Placing cases of state transformation, regime change and transitional justice in a larger historical context, inevitably requires us first to clarify the location of a particular instance within the identified historical period (eg 'decolonization'), but moreover to identify the boundaries and even justification of the 'period' itself. To stay with the example of decolonization, historians have regularly called into question a straight-forward, historic demarcation of both beginnings and ends of this 'period'. ${ }^{153}$ This has to do, inter alia, with the immensely intricate and layered context in which such a demarcation would have to be made. Surely, the context of state formation and political emancipation in North Africa in the 1960s is a different one than that of the Post-1989 political independence movements in Eastern Europe. In other words, such an exercise would have to first find convincing answers to questions such as "When did decolonization begin, when did it end - if it ever did?". Advances in comparative constitutional law point, however, to growing

\footnotetext{
150 Michel Rosenfeld, The Identity of the Constitutional Subject (2010), reproduced in part in: Norman Dorsen/Michel Rosenfeld/András Sajó/Susanne Baer, Comparative Constitutionalism. Cases and Materials. 2nd ed. (2010), 66-74, at 73

151 Yosef Hayim Yerushalmi, Zakhor (1982)

152 See the contributions by Llewellyn, Anker, Nagi and Joerges in Zumbansen \& Buchanan eds., Rights, Development and Transitional Justice, Hart 2011 - forthcoming.

153 See eg Jürgen Osterhammel/Niels P. Petersson, Globalization: A Short History (2004); Paul Smith
} 
anxieties among scholars to suggest such answers. For example, comparative scholarship focusing on South East Asia, highlights the great diversity in 'postcolonial' development. ${ }^{154}$ Similar problems of classification arise through the lens of legal transplants, which might be applied in order to trace the respective normative and institutional 'migrations' of legal instruments through time and space. Here, again, we see that the story is anything but straightforward. ${ }^{155}$

Yet another problem in the context of applying a 'governance' lens to the comparative study of constitutional cultures arises from the extreme volatility of normative regimes today. A governance view on these developments would at first glance reveal such volatility, in other words the fragile balance between 'hard' and 'soft' institutions in the (re-)formation of a legal-political system, in the context of 'developing nations. ${ }^{156}$ It should not come as a surprise here, that scholars engaging in the study of so-called 'new institutional economics' 157 would find this hybridity of the emerging 'economics of governance'158 less daunting, as it would only underline the ordinary tension between individual/collective societal activity on the one hand and state intervention/regulation on the other. NIE scholars have been focusing on this tension with greater emphasis in constellations of 'lawlessness', arising for example - but not only - in contexts of state transformation. ${ }^{159}$ Rather than being attributions made in the context of post-conflict situations or fundamental regime change, NIE scholars's observations of lawlessness are based as well on a normative assessment of 'state failure'. The latter is affirmed where the state falls short of providing the appropriate regulatory framework for private activity. Hence, the NIE scholars's insistence on the need of 'private ordering'. ${ }^{160}$ It is important to recognize that the analysis of lawlessness does not exhaust itself nor grow out of studies of development contexts. Instead, the analysis unfolds very powerfully in the midst of mature and as such highly regulated nation-state environments, where the target of NIE scrutiny is the state's assertion of regulatory authority over what would

\footnotetext{
154 Albert H.Y. Chen, Western Constitutionalism in Southeast Asia: Some Historical and Comparative Observations, http://www.ssrn.com/abstract $=1723658$

155 Sujit Choudhry, 'Globalization in Search of Justification: Toward a Theory of Comparative Constitutional Interpretation', (1999) Indiana Law Journal 819-892

156 Telling: Oliver E. Williamson, The Mechanisms of Governance (1996), ch. 6; see also Richard A. Posner, 'Creating a Legal Framework for Economic Development', (1998) 13 The World Bank Research Observer 1-11

157 For an insightful account, see Oliver E. Williamson, 'The New Institutional Economics: Taking Stock, Looking Ahead', (2000) 38 Journal of Economic Literature 595-613; see also Elinor Ostrom, 'Challenges and growth: the development of the interdisciplinary field of institutional analysis', (2007) 3 Journal of Institutional Economics 239-264, 242-243

158 Williamson, 2005; for a discussion see Calliess and Zumbansen, 2010, ch. 2, part III, C i. (pp. 113119)

159 Dixit 2004

160 Williamson, 1996, 2005
} 
allegedly better be left to the self-regulatory capabilities of private actors. ${ }^{161}$ The assignment of law to set but the formal framework for societal self-regulation draws on legal sociological insights into the normative pluralism of complex societal settings ${ }^{162}$, but gives this analysis a conservative twist by drawing a line between the spheres of the 'state' and the 'market' and between the 'public' and the 'private', despite a longstanding refutation of such simplifying and thus misleading distinctions. ${ }^{163}$

This brief allusion to the themes of 'lawlessness' and 'private ordering' suggests an altogether ambiguous concept of the constitution, which is at work both in the context of developing states but also mature welfare states. Whereas the term constitution could refer to a - written or unwritten - text or set containing the ground-rules of state conduct and civil rights, the struggle over the place of law in the evolution of political orders, then and now, suggests a much more comprehensive concept of the constitution. Such a concept becomes discernible from a political economy perspective, which - since Adam Smith - has referred to the constitution as the framework of state-market relations. ${ }^{164}$ From that perspective, constitution captures the organization and normative ordering of a particular society. Where from the vantage point of the earlier depiction rendered by the new institutional economics scholars, the constitution would refer to the rules and principles setting out the rights of both the state and the people living within it, a political economy perspective on the constitution would seek to capture all regulation to be part of the constitutional structure.

As a result, a historical periodization of constitutional phases in different parts of the world would face the choice of either having to assume at least a basic form of constitutional standards and ground-rules, against which such changes could be measured, or giving up entirely on the idea of historical periodization for the purpose of comparative studies of constitutional developments in light of the complexity and particularity of each individual case.

\section{The Form and Substance of Constitutionalism}

But how, we must then ask, can this complex background be encompassed and adopted by the notion of constitutionalism? This ambivalence is implied by constitutionalism's fusion of form and substance of government. It is here where we can already recognize the vulnerability of constitutional design to an usurpation by normative motivations, which are themselves removed from scrutiny, because they hide a qualitative dimension ('what should states do?'; 'what do we mean by state?')

\footnotetext{
161 See eg Hadfield and Talley, 2008; Hadfield, 2009.

162 Ehrlich 1913; Moore, 1978; Arthurs, 1985; Grifftiths, 1986; Merry 1988

163 Hale 1923; M Cohen 1927

164 Smith 1723; Marx Manuscripts 1944;
} 
underneath an allegedly quantitative measurement in terms of "Where to draw the limits of state intervention?". In turn, this association of constitutionalism with the notion of 'limiting' government remains politically innocent and vulnerable for just about any inscription of what governments should or should not do: by reorienting what is really a normative decision about the goals of politics to the quantifiable measurements of state action, the fact that at the outset we were concerned with a normative question is effectively invisibilised.

But herein rests its great vulnerability, as constitutionalism, stripped of its institutional embodiment on the one hand and being relatively defenseless in its reliance on a commitment to 'limiting government' on the other, is exposed to normative usurpation. Such usurpation can originate from just about any corner of society, perceived as functionally differentiated and structured by a disharmonious - concert of different communicative rationalities. "The administrative individualism of optimizing a rational conduct of life and the global moral missionary consciousness are two sides of the same coin." 165 But, then again, the usurpation will not come from just any force of societal rationality, or simply originate out of functional differentiation without particular pulls and dynamics. In a knowledge society, marked by the ubiquitous presence of 'experts', practical judgment can tend to become clouded.166 Meanwhile, certain 'rationalities', foremost the economic one, have become particularly influential and 'expansive'.167 As has repeatedly been noted by skeptics of the 'new constitutionalism' 168 , this has tremendous repercussions for the use of the concept to depict emerging forms of societal order on the transnational plane. In accordance with the ubiquitous triumph of economic rationality, myriad forms of private authority and empowerment, based on property rights and contractual freedom, have become the driving forces in a fast expanding transnational space of market 'self-regulation'. It is here, at least from a Western perspective ${ }^{169}$ that the concept of constitutionalism merges with processes of 'constitutionalization'. In the grey zone between constitutionalism and constitutionalization, the former is above all associated with the erosion of institutionalized, accountable exercises of political, while the latter

\footnotetext{
165 Somek, 'Verfassung', 145

166 Id.

167 Gunther Teubner, 'Justice under Global Capitalism?' (2008) 1 European Journal of Legal Studies 18 [http://cadmus.eui.eu/dspace/bitstream/1814/10217/1/EJLS_2008_1_3_TEU_En.pdf], 6.
}

168 David Schneiderman, 'Transnational Legality and the Immobilization of Local Agency', (2006) 2 Annual Review of Law and Social Sciences 387-408; Cutler, 2003; see already Detlev F. Vagts, 'The Multinational Enterprise: A New Challenge for Transnational Law', (1969) 83 Harvard Law Review 739-792.

169 Compare with Jiunn-Rong Yeh, 'The Emergence of Asian Constitutionalism: Features in Comparison', (2009) 4 National Taiwan University Law Review 39-53, 47-49, stressing the 'thin understanding of liberal constitutionalism', whereby constitutional change in Asia in recent decades has - different to the transitional context in Eastern Europe - not been focused on market transformation, but on the simultaneous, non-oppositional development of liberal and social rights. 
appears to capture the formative but disembedded driving forces of constitutionmaking. In this juxtaposition, constitutionalism still rings of the, if embattled and contested, glory of a constitutional promise, a text and its adversaries, while constitutionalization no more than ironicizes particular places of constitutional culture. In an evolving, transnational space, constitutionalization is the driver, wakeup call and désenchanteur of a reliable constitutional culture.

In a multi-vocal and fragmented and diversified universe of beliefs, traditions and knowledge bodies, the constitutionalism which grows out of the constitutionalization of societal practices, has little in common with the world of 'comparative' constitutional law. Constitutionalization, in the transnational space, depicts the dynamic forces of constantly newly emerging functional and specialized fora of rule-making. ${ }^{170}$ In this new environment, constitutionalism's central task to bring about a new fusion of form and substance of government, is always at risk of normative hijacking. In other words, by giving up the intricate tension within the constitution as both emancipating and limiting, the normative core of constitutionalism, so understood, can easily be oriented this way or that, through just about any dominant normative concept, the substance of which has never been subjected to a legitimizing process. ${ }^{171}$

And thus, it comes as no surprise that the intricate nature of this inner connection between form and substance of government must remain ambivalent. One way of addressing this situation, has been to distinguish between constitutionalism and democracy. ${ }^{172}$ The latter serves as both a yardstick for an assessment of the procedural and institutional safeguards of constitutionalism and a normative counter-position to the ambiguous openness of constitutionalism. But, how convincing is this move in light of the fact that the contours of democratic government have become elusive in a world society without world government?

\section{Societal Constitutionalism: Law's Troubled Relation to Society}

\footnotetext{
170 On point: Martin Loughlin, 'What is Constitutionalization?' in Martin Loughlin (ed) The Twilight of Constitutionalism? (2010).

171 Petra Dobner, 'More Law, less Democracy? Democracy and Transnational Constitutionalism', in Petra Dobner (ed) The Twilight of Constitutionalism? (2010); Alexander Somek, 'The argument from transnational effects II: Establishing transnational democracy', (2010) 16 European Law Journal 375395, depicting the unresolved nature of legitimacy in 'Global Administrative Law' as evidence for an assumed, but not scrutinized natural law basis of the project.

172 Jeremy Waldron, 'Constitutionalism: A Skeptical View', (2010) New York University Public Law \& Legal Theory Research Paper No. 10-87 http://ssrn.com/abstract=1722771, 40: "Constitutions are not just about retraining and limiting power; they are about the empowerment of ordinary people in a democracy and allowing them to control the sources of law and harness the apparatus of government to their legitimate expectations. That is the democratic view of constitutions, but it is not the constitutionalist view."
} 
Today, constitutional scholars must address questions of constitutional design, including the negotiation of political power and fundamental rights ${ }^{173}$ against this background of a changed and continuously changing regulatory environment. The general transformation of state sovereignty from 'above' must be seen in tandem with what the sociologist Saskia Sassen has coined the erosion of sovereignty from 'below', namely the alteration of formerly hierarchically conceived patterns of political and legal order through an increasing fusing of the state with market spheres of norm creation, implementation and enforcement. ${ }^{174}$ This multi-polar transformation of state functionality poses significant challenges for constitutional theories, which - as we have observed in Western legal thought - were largely developed against the background of a state-based system of political organization. As these societies are continuing to experiment with responsive, participatory and substantively more open-ended forms of regulation ${ }^{175}$, constitutional law becomes a crucial intersection forum for highly differentiated interests and demands from various sectors of society. ${ }^{176}$

But, the same dynamics which characterize and shape power relations, access and accountability on the global level under the guise of constitutionalization ${ }^{177}$ and 'good governance'178, have their counterparts within domestic legal cultures something that renders commitments to 'mutual respect' and 'trust' as core ingredients of an integrative constitutionalist culture ${ }^{179}$ considerably

173 Carl Schmitt, Constitutional Theory (Jeffrey Seitzer transl. [orig. German 1928]) (2008)

174 Saskia Sassen, 'The State and Globalization', in Saskia Sassen (ed) Governance in a Globalizing World (2000)

175 Philippe Nonet/Philip Selznick, Law and Society in Transition. Toward Responsive Law (1978); Gunther Teubner, 'Substantive and Reflexive Elements in Modern Law', (1983) 17 Law \& Society Review 239-285; Gunther Teubner, 'Autopoiesis in Law and Society: A Rejoinder to Blankenburg', (1984) 18 Law \& Society Review 291-301

176 Karl-Heinz Ladeur, 'Risiko Sozialstaat. Expansion des Sozialstaats ohne verfassungsrechtliche Schranken', (2007) 46 Der Staat 61-88; Karl-Heinz Ladeur, 'Staat und Gesellschaft. Von der liberalen zur postmodernen Gesellschaft', in Karl-Heinz Ladeur (ed) Verfassungstheorie (2010); Ernest A. Young, 'The Constitution outside the Constitution', (2007) 117 Yale Law Journal 408-473; and see already Niklas Luhmann, 'Verfassung als evolutionäre Errungenschaft', (1990) 9 Rechtshistorisches Journal 176-220.

177 David Schneiderman, 'Realising Rights in an Era of Economic Globalisation: Discourse Theory, Investor Rights, and Broad-Based Black Economic Empowerment', in David Schneiderman (ed) Redefining Sovereignty in International Economic Law (2008)

${ }^{178}$ Kerry Rittich, 'Functionalism and Formalism: Their latest Incarnations in Contemporary Development and Governance Debates', (2005) 55 University of Toronto Law Journal 853-868

179 Dieter Grimm, 'Integration by Constitution', (2005) 3 International Journal of Constitutional Law 191-210; Neil Walker, 'Taking Constitutionalism Beyond the State', (2008) 56 Political Studies 519543,531 
aspirational. ${ }^{180}$ With a view to the transformation of the state, depicted through notions such as the 'rule of law'181, the 'social'182, 'welfare'183, or 'post-regulatory' state $^{184}$, the realm of constitutional law has long begun to become unbounded. Especially in fast-capitalizing, Western nation states, we can look back at a long history of crucial challenges to the regulatory nature of constitutional law. The history and experience of constitutional law in these societies is of greatest importance precisely because it provides for such a rich archive and mine of engagements with problems of inclusion and exclusion, access and redistribution, public and private power, which so markedly haunt global governance today. ${ }^{185}$ Strikingly, however, little of this varied history, full of ambiguity, violence, frustration and compromise ${ }^{186}$, seems to shape the global constitutional imagination. The assertion of, say, Global Administrative Law's 'constitutional modesty'187 in contrast to global constitutionalism's alleged 'immodesty' is hardly convincing. After all we remain concerned with the transfer of administrative law principles and concepts, which historically have evolved in the context of constitutional contestation, into a sphere, that would allegedly allow a separation of the procedural rules of political administration of highly diversified interests and power relations from underlying constitutional conflicts. ${ }^{188}$

180 Gunther Teubner, 'Fragmented Foundations: Societal Constitutionalism beyond the Nation State', in Gunther Teubner (ed) The Twilight of Constitutionalism? (2010), 341: “... one can only be amazed at the naivety of participatory romanticism."

181 Allan C. Hutchinson/Patrick Monahan (eds), The Rule of Law: Ideal or Ideology (1987)

182 Michael Stolleis, 'Die Entstehung des Interventionsstaates und das öffentliche Recht', (1989) 11 ZNR 129-147

183 Francois Ewald, L'Etat providence (1986)

184 Colin Scott, 'Regulation in the Age of Governance: The Rise of the Post Regulatory State', in Colin Scott (ed) The Politics of Regulation: Institutions and Regulatory Reforms for the Age of Governance (2004)

185 Nancy Fraser, Scales of Justice. Reimagining Political Space in a Globalizing World (2009); Partha Chatterjee, The Politics of the Governed. Reflections on Popular Politics in Most of the World (2004), 59

ff; Rudolf Stichweh, Inklusion und Exklusion. Studien zur Gesellschaftstheorie (2005), 45 ff; Niklas Luhmann, Law as a Social System (K Ziegert transl., F Kastner, D Schiff, R Nobles, R Ziegert eds.) (2004), ch. 12.; Neil Walker, 'Taking Constitutionalism Beyond the State', (2008) 56 Political Studies 519-543, 540: "a powerful continuing counterpoint".

186 Robert M. Cover, 'Nomos and Narrative', (1983) 97 Harvard Law Review 4-68; Philippe Nonet/Philip Selznick, Law and Society in Transition. Toward Responsive Law (1978); Daniel T. Rodgers, Atlantic Crossings. Social Politics in a Progressive Age (1998)

187 Nico Krisch, 'Global Administrative Law and the Constitutional Ambition', (2009) LSE Law, Society and Economy Working Papers 10/2009 http://ssrn.com/abstract=1344788, for a critique, see Alexander Somek, 'The argument from transnational effects II: Establishing transnational democracy', (2010) 16 European Law Journal 375-395, and Somek, Administration without Sovereignty, in Dobner/Loughlin, op. cit., $267 \mathrm{ff}$.

188 For a rescue attempt, see Kingsbury 2009. 
The fluidity of institutional structures in the emerging 'network society' suggests that constitutional law, based either on a text or emerging from historical common law practice, is best seen as a forum through which an endless number of linkages are constantly created, processed, changed, rejected and affirmed, between law and politics. 'Constitution', then, becomes an anchoring point and reference perspective for the collision of existing and emerging legal semantics of society's selfgovernance. But, as such, the constitution is no longer a 'public law' text, emanating from state authority and sitting at the pinnacle of a pyramid of legal normativity. Instead, constitutions - written or unwritten - and constitutional law must facilitate the intersection of law and politics in a radically heterarchic, modern society, thereby giving a fresh meaning to the sphere and institutional architecture of politics as such. ${ }^{189}$ As a consequence, the strict confines of the traditionally conceived subject matter of constitutional law itself have long begun to elude us. ${ }^{190}$

What does this mean, however, for the task pursued by comparative constitutionalists? Much suggests that comparative constitutional law has itself become fundamentally affected by a change in law's self-perception of its foundations, instruments and institutions. Rather than with the 'laws' of, say, in jurisdiction $\mathrm{A}$ and jurisdiction $\mathrm{B}$, comparative lawyers, and notably comparative constitutional law scholars, find themselves confronted with a complex, multilayered and hybrid structure of norms. Taking their cue from Zweigert and Kötz' instruction in functional comparisons ${ }^{191}$, such comparativists are today caught in a web of official and inofficial, 'hard' and 'soft' norms, that render a comparison of legal instruments and regulatory regimes much more challenging. ${ }^{192}$ At the heart of comparing legal cultures now lies an unavoidably interdisciplinary study of legal and non-legal norms, routines and social practices.193 It is here, where the comparativist cannot fruitfully proceed without drawing on the insights from 'neighbouring' as well as complementing disciplines - both from outside and inside law. Through the interaction and engagement with political scientists, anthropologists, administrative law and legal pluralism scholars, to mention only a few, comparative constitutionalists will be poised to draw a much more accentuated map of constitutional culture and change. It is here where we can catch a glimpse of

189 Niklas Luhmann, 'Verfassung als evolutionäre Errungenschaft', (1989) 9 Rechtshistorisches Journal 176-220; Niklas Luhmann, Political Theory in the Welfare State [1981, transl. by John Bednarz Jr.] (1990)

190 Jeremy Waldron, 'Constitutionalism: A Skeptical View', (2010) New York University Public Law \& Legal Theory Research Paper No. 10-87 http://ssrn.com/abstract=1722771.

191 Konrad Zweigert/Hein Kötz, An Introduction to Comparative Law, 3rd ed. (1996), 34 ff

192 See eg David C. Donald, 'Approaching Comparative Company Law', (2008) 14 Fordham Journal of Corporate and Financial Law 83-178.

193 H. Patrick Glenn, Legal Traditions of the World: Sustainable Diversity in Law [2000] 2nd ed. (2004); Annelise Riles, 'Comparative Law and Socio-Legal Studies', in Annelise Riles (ed) Oxford Handbook of Comparative Law (2006); Peer Zumbansen, 'Comparative Law's Coming of Age? Twenty Years after

'Critical Comparisons", (2005) 6 German Law Journal 1073-1084 
what a turn towards an interdisciplinary understanding of functionalist comparisons might mean. Law's exposure to the myriad, conflicting rationalities and tendencies in a differentiating society throws law back upon itself. It must thus reflect on its own constitution. As legal doctrines, principles and regulatory standards become criss-crossed, captured, alienated, and constantly turned on their head by economic, political or religious contentions of efficiency, legitimacy or truth, the very function of law becomes questionable - or, worthy of fundamental reconsideration. It becomes a constitutional question, but one that is no longer answerable with reference to established patterns of hierarchy or authority, but in a radically open, undetermined way. Law's operation with the legal/illegal distinction is its existential self-assertion, its claim to take on board the pains of this world. It can only do so in its raw exposedness to competing regulatory rationalities, emerging from economics, politics, or religion. Meanwhile, the constitutional 'subject' itself is too often constituted from within a known, unscrutinized and closed context. ${ }^{194}$ Breaking these frames, the subject emerges as a fragile and vulnerable space of attribution, domination, and suffocation, one that can only be adequately studied in reaching beyond confines and treacherous 'inheritances'. ${ }^{195}$ Comparative constitutional law, then, withers away as a field focusing on 'comparison', on 'constitutions' and on 'law', only to reemerge as a critical enterprise in scrutinizing law's relation to a complex world society.

194 Bruno Latour, We have never been modern (Catherine Porter transl.) (1993)

195 Upendra Baxi, 'The Colonialist Heritage', in Upendra Baxi (ed) Comparative Legal Studies:

Traditions and Transitions (2003) 